\title{
Efficacy and safety outcomes of short duration antiplatelet therapy with early cessation of aspirin post percutaneous coronary intervention: a systematic review and meta-analysis
}

Firas R. AL-Obaidi (FIBMS, CABMS) ${ }^{1,2}$; Hayley A. Hutchings (PhD) ${ }^{3}$, Andy S.C. Yong (FRACP, PhD) ${ }^{4,5}$; Laith Alrubaiy (FRCP, PhD) ${ }^{6}$, Hasan Al-Farhan (FIBMS) ${ }^{7,8}$; Mohammed H. Al-Ali (CABMS, FIBMS) ${ }^{9,10}$; Tahsin Al-Kinani (FRCP, FIBMS) ${ }^{9,10}$; Mohammed AlMyahi (FRCP, FIBMS) ${ }^{10}$, Hussein Al-Kenzawi (FIBMS) ${ }^{10}$, Nazar Al-Sudani (FIBMS) ${ }^{10}$

1 Al-Zahra College of Medicine/ University of Basrah, Iraq, 2 Basra Cardiac Centre, Iraq, 3 Patient and Population Health and Informatics Research, Swansea University Medical School, Swansea University, UK, 4 Faculty of Medicine and Health Sciences, Macquarie University, Sydney, Australia, 5 ANZAC Research Institute, Concord Hospital, Sydney, Australia, 6 St Mark's Hospital and Academic Institute, UK, 7 Iraqi Scientific Council of Cardiology, Baghdad city, Iraq, 8 Baghdad Heart Centre, Medical city, Baghdad city, Iraq, 9 College of Medicine/ University of Thi Qar, Iraq, 10 Nasiriyah Heart Centre, Iraq

Corresponding author:

Dr. Firas R. AL-Obaidi, FIBMS, CABMS

AL-Zahra College of Medicine- University of Basrah

Basra Cardiac Centre

Email: firasrobaidi@gmail.com

Tele: +9647726663279

https://orcid.org/0000-0002-7163-6570

Current Cardiology Reviews 2021;17(6):e051121190712

DOI: $10.2174 / 1573403 X 17666210126104053$ 


\section{Abstract}

Background: The optimal duration of dual antiplatelet therapy is a matter of ongoing research. Clinical studies are assessing the optimal duration with the most favourable risk to benefit ratio. The efficacy of P2Y12 receptor inhibitors has been shown comparable to aspirin in preventing recurrent ischaemic events in patients with coronary artery diseases.

Objectives: To investigate the outcomes of short-duration dual antiplatelet therapy after PCI with early discontinuation of aspirin while maintaining patients on P2Y12 inhibitor through systematic review and meta-analysis of available literature.

Methods: We systematically searched Pubmed, Cochrane Central Register of Controlled Trials (CENTRAL) and ClinicalTrials.gov. We included randomised controlled studies that measured clinical outcomes of efficacy (mortality and ischaemic events) and safety (bleeding) of short and standard duration dual antiplatelet therapy. The protocol of this study was registered in the International prospective register of systematic reviews PROSPERO registry (CRD42020171468).

Results: Four randomised controlled trials were included; GLOBAL LEADERS, SMARTCHOICE, STOPDAPT-2 and TWILIGHT. The total number of patients was 29,089. The safety outcomes showed a significant reduction in major bleeding events with short-duration dual antiplatelet therapy; risk ratio is 0.61 (95\% CI $0.38-0.99 ; \mathrm{z}=2,00, \mathrm{p}=0.05)$. There was no difference between short and standard duration dual antiplatelet therapy regarding efficacy outcomes (all-cause death, major adverse cardiovascular events, myocardial infarction, stroke and stent thrombosis).

Conclusion: Short-duration dual antiplatelet therapy followed by P2Y12 inhibitor monotherapy after PCI is a feasible option and can be adopted, especially in patients with a high risk of bleeding.

\section{Keywords}


Percutaneous coronary intervention, coronary artery disease, dual antiplatelet therapy, shortduration DAPT, drug-eluting stent, P2Y12 inhibitor monotherapy

\section{Introduction}

The use of dual antiplatelet therapy (DAPT) is one of the significant advances in the management of ischaemic heart diseases since the introduction of percutaneous coronary intervention (PCI). By combining both aspirin and one of the P2Y12 receptor inhibitors, dual antiplatelet therapy (DAPT) has led to major reductions in the rate of recurrent ischemic events and more importantly coronary stent thrombosis (1-3). However, the occurrence of bleeding remains the main concern with the use of combined antiplatelet therapy $(4,5)$.

The optimal duration of DAPT is a matter of ongoing research. Clinical studies are assessing the optimal duration with the most favourable risk to benefit ratio. The European Society of Cardiology recommends DAPT to be continued for one year in patients with acute coronary syndrome whether treated invasively or conservatively. However, in high bleeding risk patients, discontinuation of P2Y12 inhibitors can be considered after six months. In patients with stable ischaemic heart disease, the recommended DAPT duration with the use of contemporary drug-eluting stents is six months after PCI and only three months in patients with bleeding concerns (6).

The P2Y12 receptor inhibitors have comparable efficacy to aspirin in preventing recurrent ischaemic events in patients with coronary artery diseases $(7,8)$. Early discontinuation of aspirin after PCI was assessed in several studies in patients with atrial fibrillation who need concurrent anticoagulation after PCI (9-12), but this approach has not been widely adopted as yet.

This study aims to examine the outcomes associated with short-duration DAPT after PCI with early discontinuation of aspirin while maintaining P2Y12 inhibitor. We undertook rigorous systematic review and meta-analysis of the literature to assess the relevant clinical outcomes.

\section{Methods}

We followed the PRISMA (Preferred Reporting Items for Systematic Reviews and MetaAnalyses) reporting guidelines in preparing this systematic review and meta-analysis (13). The protocol of this study was registered in the International prospective register of systematic reviews PROSPERO registry (CRD42020171468). 


\section{Search strategy}

We systematically searched the databases of Pubmed, Cochrane Central Register of Controlled Trials (CENTRAL) and ClinicalTrials.gov. We used the following keywords and subject headings in the search: percutaneous coronary intervention, dual antiplatelet therapy, drugeluting stent and aspirin. We restricted the search only to studies published in English after 1995.

Randomised-controlled trials investigating early discontinuation of aspirin following shortduration DAPT after PCI in adult participants (age $\geq 18$ years) were included in this metaanalysis. The intervention group was identified as patients who received short-duration DAPT consisting of aspirin and P2Y12 inhibitor for less than 6 months followed by P2Y12 inhibitor only. The control group received standard duration DAPT for 6 months or more. We only included studies that measured clinical outcomes of efficacy (mortality and ischaemic events) and safety (bleeding).

We excluded all non-randomised studies, studies with short-duration DAPT followed by aspirin only and studies with standard or longer duration of DAPT.

The safety endpoint used for this analysis was Bleeding Academic Research Consortium (BARC) type 3 or 5 bleeding (14). The efficacy endpoints included all-cause mortality, major adverse cardiovascular events (MACE), myocardial infarction (MI), stroke and stent thrombosis.

\section{Extraction of data}

Two reviewers screened the title and abstract of all retrieved articles. Full text of relevant articles was reviewed. Two independent reviewers extracted data from selected studies that met the inclusion criteria. Disagreements or inconsistencies at any step were reviewed and resolved by a third reviewer. We extracted the trial characteristics (trial registration number, year of the publication, number of participants, follow up duration, number of participating centres and location), patient characteristics (mean age, comorbidities including hypertension and DM; and percentages of stable ischaemic heart disease and acute coronary syndrome) and outcome measures (efficacy and safety endpoints) from all studies consistent with the inclusion 
criteria. We used the Cochrane Collaboration's tool for assessing the risk of bias to evaluate the quality of the included studies.

\section{Statistical analysis}

The comparison of the clinical outcomes of the short-duration versus standard DAPT was analysed by calculating the risk ratios and $95 \%$ confidence interval. A random-effect model was used to address the expected heterogeneity in the studied populations, types of P2Y12 inhibitors used and the duration of treatment and follow-up. We assessed the heterogeneity of the studies with Chi X2 test and Higgins $\mathrm{I}^{2}$ statistics. The $\mathrm{I}^{2}$ value less than $25 \%$ was considered low, $25-50 \%$ was considered to be moderate and values more than $50 \%$ were deemed to show a high probability of heterogeneity. A $p$ value of less than 0.05 was considered statistically significant. The assessment of publication bias using funnel plot tests was not done due to the small number of studies included in the analysis (less than 10) that limits the power of any test to detect real bias. Review Manager (RevMan) [Computer program]; Version 5.3, The Cochrane Collaboration; was used to undertake the statistical analysis.

\section{Results}

A total of 4 randomised controlled clinical trials investigating short-duration DAPT with early cessation of aspirin (Figure 1) were included in the meta-analysis. These are GLOBAL LEADERS (15), SMART-CHOICE (16), STOPDAPT-2 (17) and TWILIGHT (18) trials. 
Number of records identified through a search of databases (PubMed, CENTRAL and ClinicalTrials.gov)

$\mathrm{N}=\mathbf{2 0 0 6 5}$

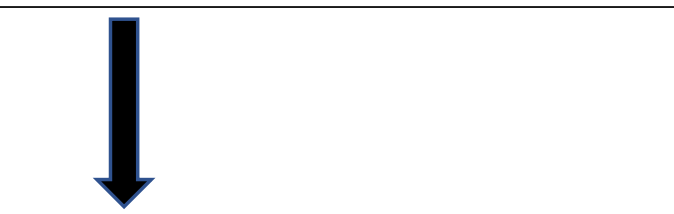

Number of records after duplicates removal $\mathrm{N}=9290$

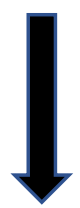

Number of records excluded after the title and abstract screening

$\mathrm{N}=9227$

Number of records screened for full text

$\mathrm{N}=63$

Number of full text records excluded $N=59$

Non-RCT studies: 42

Long duration DAPT or short duration with aspirin continuation $=\mathbf{1 7}$ 
Figure-1: PRISMA flow chart of the identification and screening process

The total number of patients enrolled in the included studies was 29,089 (14,530 in the short DAPT arm and 14,559 in the standard DAPT arm). The basic characteristics of the four studies are shown in (Table 1), and the main outcome measures applied in the studies are shown in (Table 2). The clinical presentation of the patients was stable ischaemic heart disease in 14,095 (48.45\%) patients and ACS in 14,990 (51.53\%) patients. The duration of follow up was 12-24 months in all studies.

Table-1: Trial-specific characteristics

\begin{tabular}{|c|c|c|c|c|}
\hline Characteristics & $\begin{array}{c}\text { GLOBAL } \\
\text { LEADERS }\end{array}$ & $\begin{array}{l}\text { SMART- } \\
\text { CHOICE }\end{array}$ & STOPDAPT-2 & TWILIGHT \\
\hline Year & 2018 & 2019 & 2019 & 2019 \\
\hline Patient no. & 15,968 & 2993 & 3045 & 7119 \\
\hline Female (\%) & $3714(23 \cdot 3 \%)$ & $795(26.6 \%)$ & $672(22.3 \%)$ & $1698(23.8 \%)$ \\
\hline Mean age & 64.5 years & 64.0 years & 68.6 years & 65.0 years \\
\hline Study design & $\begin{array}{l}\text { multicentre, open- } \\
\text { label, randomised } \\
\text { superiority trial } \\
\text { (18 countries) }\end{array}$ & $\begin{array}{l}\text { multi-centre, } \\
\text { open-label, } \\
\text { non-inferiority, } \\
\text { randomised trial } \\
\text { (Korea) }\end{array}$ & $\begin{array}{l}\text { multicentre, } \\
\text { open-label, } \\
\text { randomised } \\
\text { clinical trial } \\
\text { (Japan) } \\
\end{array}$ & $\begin{array}{l}\text { multi-centre, } \\
\text { double-blind, } \\
\text { randomised, } \\
\text { trial (11 } \\
\text { countries) }\end{array}$ \\
\hline Patient group & & & & \\
\hline $\begin{array}{l}\text { Acute Coronary } \\
\text { Syndrome }\end{array}$ & $\begin{array}{l}7487 / 15968 \\
(46.9 \%)\end{array}$ & $\begin{array}{l}1741 / 2993 \\
(58.2 \%)\end{array}$ & $\begin{array}{l}1148 / 3009 \\
(38.1 \%)\end{array}$ & $\begin{array}{l}4614 / 7119 \\
(64.8 \%)\end{array}$ \\
\hline $\begin{array}{l}\text { Stable Ischaemic } \\
\text { Heart Disease }\end{array}$ & $\begin{array}{l}8481 / 15968 \\
(53.1 \%)\end{array}$ & $\begin{array}{l}1250 / 2993 \\
(41.8 \%)\end{array}$ & $\begin{array}{l}1861 / 3009 \\
(61.9 \%)\end{array}$ & $\begin{array}{l}2503 / 7119 \\
(35.2 \%)\end{array}$ \\
\hline $\begin{array}{l}\text { Comorbidities } \\
\text { Hypertension }\end{array}$ & $\begin{array}{l}11715 / 15914 \\
(73.6 \%)\end{array}$ & $\begin{array}{l}1840 / 2993 \\
(61.4 \%)\end{array}$ & $\begin{array}{l}2221 / 3009 \\
(73.9)\end{array}$ & $\begin{array}{l}5154 / 7119 \\
(72.3 \%)\end{array}$ \\
\hline Diabetes Mellitus & $\begin{array}{l}4038 / 15957 \\
(25.3 \%)\end{array}$ & $\begin{array}{l}1122 / 2993 \\
(37.5 \%)\end{array}$ & $\begin{array}{l}1159 / 3009 \\
(38.5 \%)\end{array}$ & $\begin{array}{l}2620 / 7119 \\
(36.8 \%)\end{array}$ \\
\hline Stent type & $\begin{array}{l}\text { Biolimus A9- } \\
\text { eluting stent }\end{array}$ & $\begin{array}{l}\text { Xience Prime, } \\
\text { Xience } \\
\text { Expedition, } \\
\text { Xience Alpine, } \\
\text { Promus Element, } \\
\text { Promus }\end{array}$ & - & - \\
\hline
\end{tabular}




\begin{tabular}{|c|c|c|c|c|}
\hline & & $\begin{array}{l}\text { Premier, } \\
\text { SYNERGY or } \\
\text { Orsiro }\end{array}$ & & \\
\hline Follow-up duration & 2 years & 1 year & 1 year & 1 year \\
\hline Type of analysis & $\begin{array}{l}\text { intention to } \\
\text { treat }\end{array}$ & $\begin{array}{l}\text { intention-to-treat } \\
\text { and per-protocol }\end{array}$ & $\begin{array}{l}\text { intention-to- } \\
\text { treat and per- } \\
\text { protocol }\end{array}$ & $\begin{array}{l}\text { intention-to- } \\
\text { treat and per- } \\
\text { protocol }\end{array}$ \\
\hline $\begin{array}{l}\text { Trial registration } \\
\text { Number }\end{array}$ & NCT01813435 & NCT02079194 & NCT02619760 & NCT02270242 \\
\hline
\end{tabular}

Table-2: Trial-specific reported outcome measures and endpoints

\begin{tabular}{|c|c|c|c|c|}
\hline & $\begin{array}{c}\text { GLOBAL } \\
\text { LEADERS }\end{array}$ & STOPDAPT-2 & $\begin{array}{l}\text { SMART- } \\
\text { CHOICE }\end{array}$ & TWILIGHT \\
\hline $\begin{array}{l}\text { DAPT } \\
\text { regimen: } \\
\text { Experimental }\end{array}$ & $\begin{array}{l}\text { Aspirin and } \\
\text { ticagrelor } \\
\text { (1month) }\end{array}$ & $\begin{array}{l}\text { Aspirin and } \\
\text { clopidogrel or } \\
\text { prasugrel (1 month) }\end{array}$ & $\begin{array}{l}\text { Aspirin and } \\
\text { (clopidogrel or } \\
\text { prasugrel or } \\
\text { ticagrelor) } \\
\text { ( } 3 \text { months) }\end{array}$ & $\begin{array}{l}\text { Aspirin and } \\
\text { ticagrelor ( } 3 \\
\text { months) }\end{array}$ \\
\hline $\begin{array}{l}\text { Vs } \\
\text { Control }\end{array}$ & $\begin{array}{l}\text { vs } \\
\text { Aspirin and } \\
\text { clopidogrel or } \\
\text { ticagrelor } \\
\text { (12months) }\end{array}$ & $\begin{array}{l}\text { vs } \\
\text { Aspirin and } \\
\text { clopidogrel (12 } \\
\text { months) }\end{array}$ & $\begin{array}{l}\text { vs } \\
\text { Aspirin and } \\
\text { (clopidogrel or } \\
\text { prasugrel or } \\
\text { ticagrelor) } \\
\text { (12months) }\end{array}$ & $\begin{array}{l}\text { vs } \\
\text { Aspirin and } \\
\text { ticagrelor (15 } \\
\text { months) }\end{array}$ \\
\hline & & $\begin{array}{l}\text { ACS: aspirin and } \\
\text { prasugrel for } 1 \\
\text { month then aspirin } \\
\text { and clopidogrel for } \\
12 \text { months }\end{array}$ & & \\
\hline $\begin{array}{l}\text { Post-DAPT } \\
\text { regimen: }\end{array}$ & & & & \\
\hline Experimental & $\begin{array}{l}\text { Ticagrelor ( } 23 \\
\text { months) }\end{array}$ & $\begin{array}{l}\text { Clopidogrel ( } 5 \\
\text { years) }\end{array}$ & P2Y21 inhibitor & $\begin{array}{l}\text { Ticagrelor and } \\
\text { placebo ( } 12 \\
\text { months) then } \\
\text { standard of care } \\
\text { vs }\end{array}$ \\
\hline
\end{tabular}




\begin{tabular}{|c|c|c|c|c|}
\hline Control & $\begin{array}{l}\text { Aspirin (12 } \\
\text { months) }\end{array}$ & Aspirin (5 years) & $\begin{array}{l}\text { Aspirin } \\
\text { (indefinite) }\end{array}$ & standard of care \\
\hline $\begin{array}{l}\text { Primary } \\
\text { endpoints: }\end{array}$ & $\begin{array}{l}\text { All-cause death } \\
\text { or new Q-wave } \\
\text { myocardial } \\
\text { infarction }\end{array}$ & $\begin{array}{l}\text { Composite of } \\
\text { cardiovascular death, } \\
\text { myocardial } \\
\text { infarction, definite } \\
\text { stent thrombosis, } \\
\text { ischemic or } \\
\text { hemorrhagic stroke, } \\
\text { or TIMI major or } \\
\text { minor bleeding }\end{array}$ & $\begin{array}{l}\text { composite of } \\
\text { all-cause } \\
\text { mortality, } \\
\text { myocardial } \\
\text { infarction, or } \\
\text { stroke }\end{array}$ & $\begin{array}{l}\text { BARC type } 2,3, \\
\text { or } 5 \text { bleeding }\end{array}$ \\
\hline $\begin{array}{l}\text { Secondary } \\
\text { endpoints: }\end{array}$ & $\begin{array}{l}\text { 1/ BARC grade } 3 \\
\text { or } 5 \text { bleeding. } \\
\text { 2/ Composite } \\
\text { endpoint of all- } \\
\text { cause death, new } \\
\text { Q-wave } \\
\text { MI, or stroke. } \\
\text { 3/ Myocardial } \\
\text { infarction. } \\
\text { 4/ Stroke. } \\
\text { 5/ Target vessel } \\
\text { or any } \\
\text { revascularization. } \\
\text { 6/ Definite } \\
\text { stent thrombosis. }\end{array}$ & $\begin{array}{l}\text { 1/Cardiovascular } \\
\text { endpoint: composite } \\
\text { of cardiovascular } \\
\text { death, myocardial } \\
\text { infarction, definite } \\
\text { stent thrombosis } \\
\text { 2/ Bleeding } \\
\text { endpoint: TIMI } \\
\text { major } \\
\text { or minor bleeding } \\
\text { 3/ Death } \\
\text { 4/ MI } \\
\text { 5/ Definite stent } \\
\text { thrombosis } \\
\text { 6/ Probable or } \\
\text { definite stent } \\
\text { thrombosis } \\
\text { 7/ Stroke } \\
\text { 8/ Bleeding (TIMI, } \\
\text { BARC, GUSTO, } \\
\text { intracranial, } \\
\text { gastrointestinal) } \\
\text { 8/ Death or } \\
\text { myocardial } \\
\text { infarction } \\
\text { 9/Cardiovascular } \\
\text { death or myocardial } \\
\text { infarction }\end{array}$ & $\begin{array}{l}\text { 1/ All cause } \\
\text { death } \\
\text { 2/Myocardial } \\
\text { infarction } \\
\text { 3/Stroke } \\
\text { 4/Cardiac death } \\
\text { 5/stent } \\
\text { thrombosis } \\
\text { 6/ BARC type } \\
\text { 2-5 } \\
\text { 7/BARC } 3 \text { or } 5\end{array}$ & $\begin{array}{l}\text { 1/ Death from any } \\
\text { cause, nonfatal } \\
\text { myocardial } \\
\text { infarction, or } \\
\text { nonfatal stroke } \\
\text { 2/ Death from } \\
\text { cardiovascular } \\
\text { causes, nonfatal } \\
\text { myocardial } \\
\text { infarction, or } \\
\text { nonfatal } \\
\text { ischemic stroke } \\
\text { 3/ALL cause death } \\
\text { 4/Cardiovascular } \\
\text { death } \\
\text { 2/Myocardial } \\
\text { infarction } \\
\text { 3/ Ischemic stroke } \\
\text { 4/Bleeding: } \\
\text { BARC type } 3 \text { or } 5 \\
\text { TIMI (major or } \\
\text { minor) } \\
\text { GUSTO } \\
\text { ISTCH } \\
\text { 5/ Stent } \\
\text { thrombosis, } \\
\text { definite or } \\
\text { probable }\end{array}$ \\
\hline
\end{tabular}




\begin{tabular}{|l|l|l|l|}
\hline & $\begin{array}{l}\text { 11/ Major adverse } \\
\text { cardiac events } \\
10 / \text { Revascularization }\end{array}$ & & \\
\hline
\end{tabular}

All studies assessed the outcomes of using short-duration DAPT $(\leq 3$ months aspirin and P2Y12 inhibitor) followed by P2Y12 inhibitor monotherapy against standard duration DAPT (12 months aspirin and P2Y12 inhibitor). The duration of DAPT in the short arm was 1 month in both GLOBAL LEADERS and STOPDAPT-2, and 3 months in both SMART-CHOICE and TWILIGHT trials. All studies discontinued aspirin after the indicated time and continued patients on P2Y12 inhibitor monotherapy in the interventional group. The type of P2Y12 inhibitor in the interventional group was ticagrelor in both GLOBAL LEADERS and TWILIGHT studies. For STOPDAPT-2, clopidogrel or prasugrel was used during the DAPT phase, and only clopidogrel was used during the monotherapy phase. In the SMART-CHOICE trial, the type of P2Y12 inhibitor was either clopidogrel, prasugrel or ticagrelor.

We assessed the studies for the risk of bias and found them to be of high quality overall. The design of the study was open-label in the three (GLOBAL LEADERS, SMART-CHOICE and STOPDAPT-2) trials while the TWILIGHT study had a double-blind design. Event adjudication was performed by independent committees in all the studies except in the GLOBAL LEADERS.

To address the risk of bias, further sub-analysis was done by enrolling the GLASSY substudy to replace the GLOBAL LEADERS trial (19). The GLASSY sub-study evaluated the data of 7,585 patients (47.5\% of the overall patients enrolled in the GLOBAL LEADERS trial) with 3,794 patients in the experimental arm and 3,791 patients in the control arm. The sub-study aimed to overcome significant limitations in the parent study by reporting the results through an independent clinical event committee to adjudicate investigator-reported 
outcomes. The protocol of the sub-study was similar to the experimental group received 1month DAPT (aspirin plus ticagrelor) followed by 23-month ticagrelor monotherapy vs the control group with 12-month DAPT followed by aspirin alone for 12 months. The efficacy primary endpoint was more inclusive in the sub-study and included a composite endpoint of death, MI, stroke, or urgent target vessel revascularization (TVR). Safety outcomes were analysed as co-primary endpoint while in the parent study, safety outcomes analysed as secondary endpoints. The statistical analysis designed for both non-inferiority and superiority targets. Data analysis provided data at 1, 12 and 24 months follow up.

The secondary analysis was done at 12-month interval from all included studies. These data were available for the GLASSY sub-study but not the GLOBAL LEADERS trial.

\section{Safety endpoints}

The risk of major bleeding was evaluated using different scores in the four trials. The Bleeding Academic Research Consortium (BARC) type 3 or 5 bleeding was the only score that was reported across all included studies and was therefore included in this meta-analysis. The analysis shows higher bleeding rate in the standard DAPT group, but this did not reach statistical significance (Figure-2 A). The BARC type 3 or 5 bleeding was 217/14530 in the short DAPT vs 279/14559 in the control group, risk ratio is 0.62 (95\% CI 0.37-1.05; $\mathrm{z}=1.79$, $\mathrm{p}=0.07)$. The risk of heterogeneity was high, with $\mathrm{I}^{2}=79 \%$.

However, in the secondary analysis, the results of the GLASSY sub-study of the GLOBAL LEADERS trial were included instead. The safety outcomes showed a significant reduction of major bleeding events with short DAPT (124/10344 with short DAPT vs 186/10362 with standard DAPT), risk ratio is 0.61 (95\% CI $0.38-0.99 ; \mathrm{z}=2,00, \mathrm{p}=0.05)$. The risk of heterogeneity is moderate $\mathrm{I} 2=71 \%$ (Figure-3 A).

\section{Efficacy endpoints}

We analysed the data of the efficacy outcomes represented by the ischaemic events rate in relation to the duration of the DAPT. The meta-analysis was conducted for the endpoints of all-cause death, MACE, myocardial infarction, stroke and stent thrombosis (Figure-2 B-F). 
Figure-2: Forest plot for major bleeding a all-causes death, MACE ${ }^{\text {b }}$, myocardial infarction, stroke and stent thrombosis

\section{A- Major bleeding}

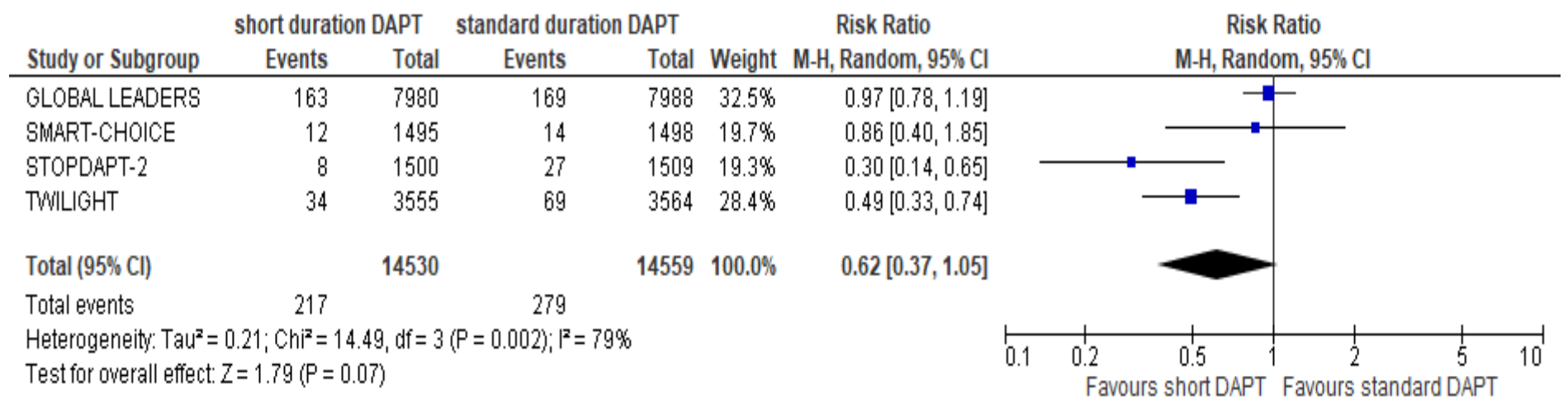

\section{B- All-cause death}

\begin{tabular}{|c|c|c|c|c|c|c|c|c|c|}
\hline \multirow[b]{2}{*}{ Study or Subgroup } & \multicolumn{2}{|c|}{ short duration DAPT } & \multicolumn{2}{|c|}{ standard duration DAPT } & \multicolumn{2}{|r|}{ Risk Ratio } & \multirow{2}{*}{\multicolumn{2}{|c|}{$\begin{array}{c}\text { Risk Ratio } \\
\text { M-H, Random, } 95 \% \mathrm{Cl}\end{array}$}} & \\
\hline & Events & Total & Events & Total & Weight & M-H, Random, $95 \% \mathrm{Cl}$ & & & \\
\hline GLOBAL LEADERS & 224 & 7980 & 253 & 7988 & $75.7 \%$ & $0.89[0.74,1.06]$ & & & \\
\hline SMART-CHOICE & 21 & 1495 & 18 & 1498 & $6.1 \%$ & $1.17[0.63,2.19]$ & & & \\
\hline STOPDAPT-2 & 21 & 1500 & 18 & 1509 & $6.1 \%$ & $1.17[0.63,2.19]$ & & & \\
\hline TWILIGHT & 34 & 3555 & 45 & 3564 & $12.1 \%$ & $0.76[0.49,1.18]$ & & & \\
\hline $\begin{array}{l}\text { Heterogeneity: Tau } \\
\text { Test for overall effect }\end{array}$ & $\begin{array}{l}00 ; \mathrm{Chi}^{2}= \\
=1.35(\mathrm{P}=\end{array}$ & $\mathrm{df}=3($ & $P=0.58) ;\left.\right|^{2}=0$ & & & & $0.1 \quad 0.2$ & $\begin{array}{ccc}0.5 & 1 & 2 \\
\text { short DAPT } & \text { Favours st }\end{array}$ & \begin{tabular}{|c|}
5 \\
5 DAPT
\end{tabular} \\
\hline
\end{tabular}

\section{C- Major Adverse Cardiovascular Events (MACE)}


Short duration DAPT Standard duration DAPT

Risk Ratio

Risk Ratio

\begin{tabular}{lrrrrrr} 
Study or Subgroup & Events & Total & Events & Total & Weight & M-H, Random, 95\% Cl \\
\hline GLOBAL LEADERS & 362 & 7980 & 416 & 7988 & $65.5 \%$ & $0.87[0.76,1.00]$ \\
SMART-CHOICE & 42 & 1495 & 36 & 1498 & $6.4 \%$ & $1.17[0.75,1.81]$ \\
STOPDAPT-2 & 29 & 1500 & 37 & 1509 & $5.3 \%$ & $0.79[0.49,1.28]$ \\
TWILIGHT & 135 & 3555 & 137 & 3564 & $22.8 \%$ & $0.99[0.78,1.25]$ \\
& & & & & & \\
Total (95\% Cl) & & 14530 & & 14559 & $100.0 \%$ & $0.91[0.81,1.02]$ \\
Total events & 568 & & 626 & & &
\end{tabular}

Heterogeneity: Tau $^{2}=0.00 ; \mathrm{Chi}^{2}=2.45, \mathrm{df}=3(\mathrm{P}=0.48) ; \mathrm{I}^{2}=0 \%$

Test for overall effect: $Z=1.69(P=0.09)$

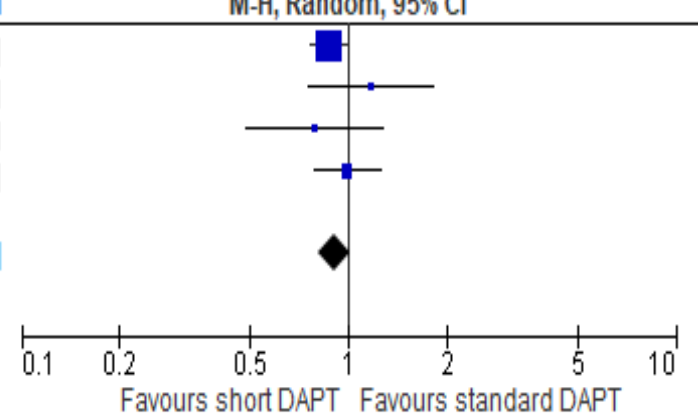

\section{D- Myocardial infarction}

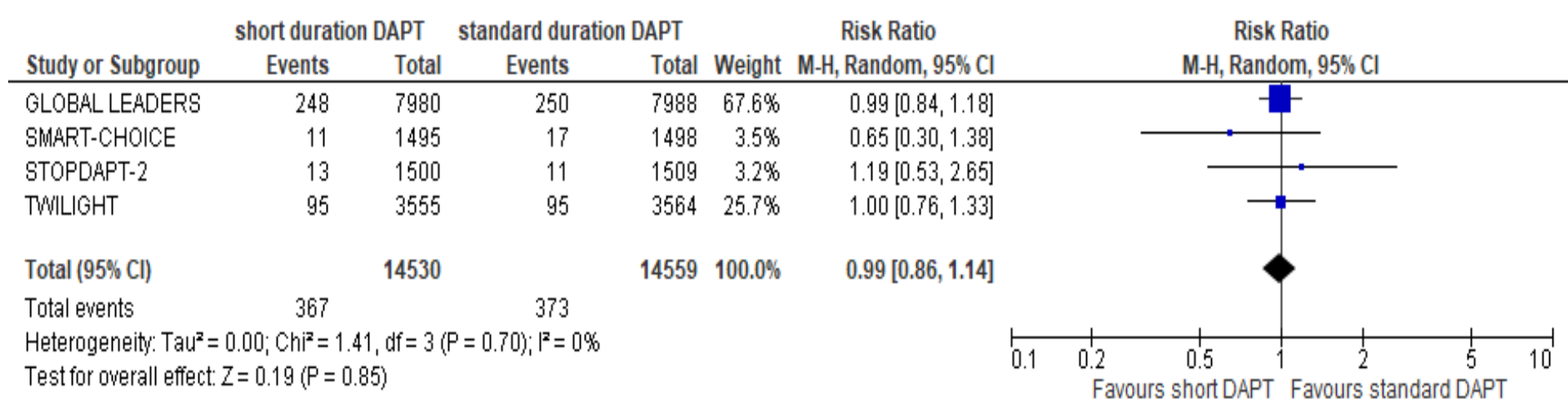

\section{E- Stroke}

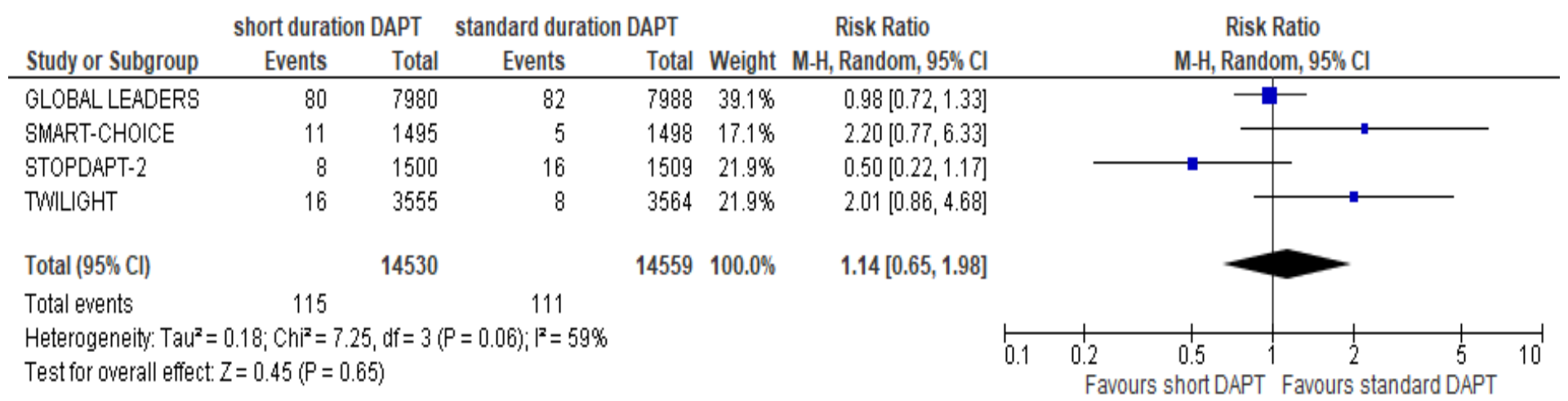

\section{F- Stent thrombosis}




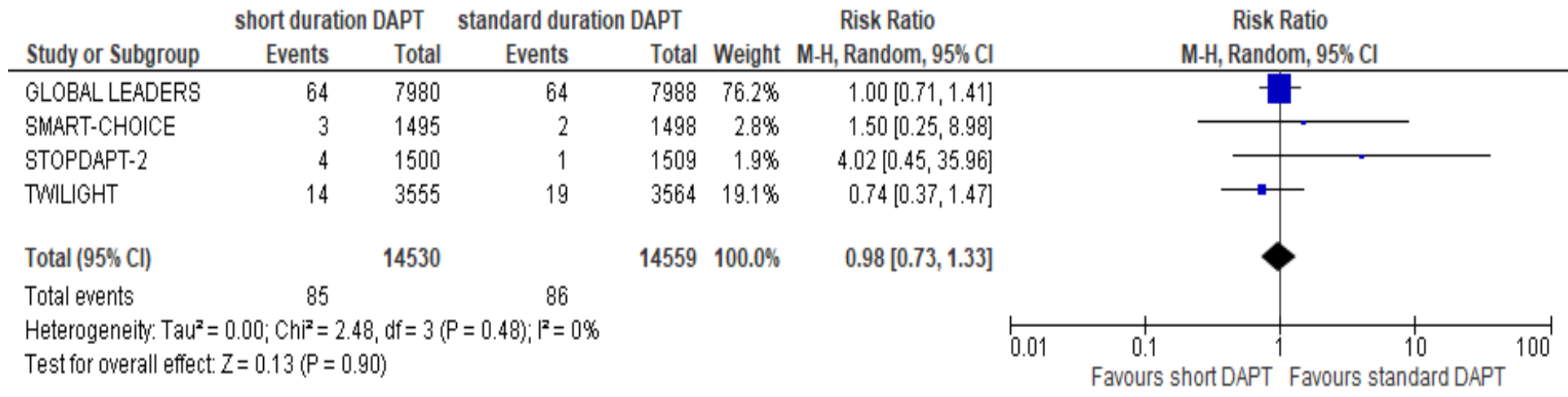

a: BARC type 3 to 5 bleeding.

b: Major Adverse Cardiovascular Events (composite of all-cause mortality, myocardial infarction, or stroke).

Regarding all-cause mortality, there was no significant difference between short DAPT (300/14530) and standard DAPT (334/14559) (Figure-2 B), the risk ratio was 0.90 (95\% CI $0.77-1.05 ; \mathrm{z}=1.35, \mathrm{p}=0.18)$ with a low risk of heterogeneity $\left(\mathrm{I}^{2}=0 \%\right)$.

The rate of MACE was not significantly different between the two groups (568/14530 with short DAPT vs 625/14559 with standard DAPT) (Figure 2 C), risk ratio 0.91 (95\% CI 0.81$1.02 ; \mathrm{z}=1.69, \mathrm{p}=0.09)$ with a low risk of heterogeneity $\left(\mathrm{I}^{2}=0 \%\right)$.

Similarly, no significant difference was found for myocardial infarction (367/14530 with short DAPT vs 373/14559 with standard DAPT (Figure 2 D), risk ratio 0.99 (95\% CI 0.86-1.14; $\mathrm{z}=0.19, \mathrm{p}=0.85$ ), with low risk of heterogeneity $\mathrm{I}^{2}=0 \%$.

For stroke, the rate in each group was similar 115/14530 with short DAPT vs 111/14559 with standard DAPT (Figure 2 E), risk ratio 1.14 (95\% CI 0.65-1.98; z=0.45, p=0.65), with a high risk of heterogeneity $\mathrm{I}^{2}=59 \%$. The rate of stent thrombosis was also comparable 85/14530 with short DAPT and 86/14559 with standard DAPT (Figure 2 E), risk ratio 0.98 (95\% CI 0.73$1.33, \mathrm{z}=0.13, \mathrm{p}=0.90$ ) with low risk of heterogeneity $\mathrm{I}^{2}=0 \%$.

The outcomes of the efficacy were similar in the secondary analysis with no difference for allcause death, MACE, MI, stroke and stent thrombosis between the two groups (Figure-3 B-F). 
Figure-3: Forest plot for major bleeding, all-causes death, MACE, myocardial infarction, stroke and stent thrombosis using GLASSY sub-study of GLOBAL LEADERS trial

\section{A. Major bleeding}

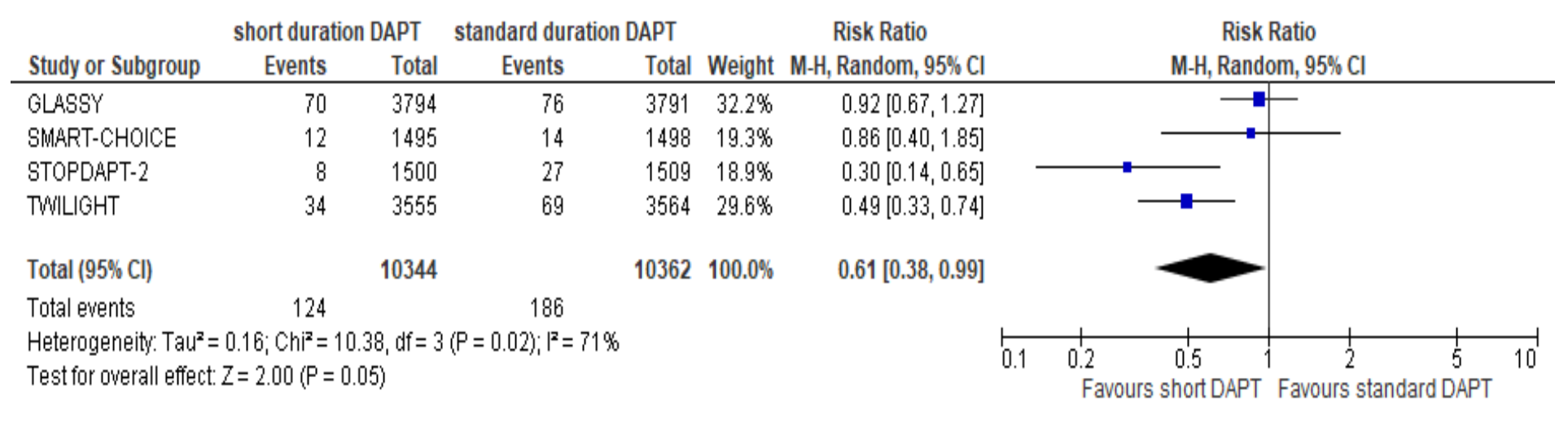

\section{B. All-cause death}

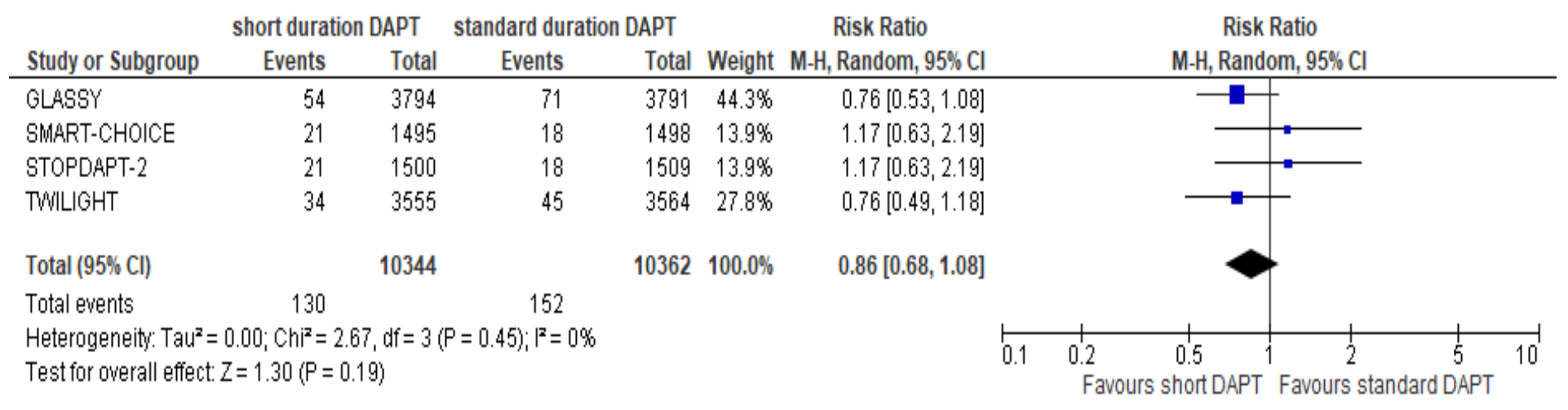

\section{Major Adverse Cardiovascular Events (MACE)}

\begin{tabular}{|c|c|c|c|c|c|c|c|c|c|}
\hline \multirow[b]{2}{*}{ Study or Subgroup } & \multicolumn{2}{|c|}{ Short duration DAPT } & \multicolumn{2}{|c|}{ Standard duration DAPT } & \multirow{2}{*}{ Weight } & \multirow{2}{*}{$\begin{array}{c}\text { Risk Ratio } \\
\mathrm{M}-\mathrm{H}, \text { Random, } 95 \% \mathrm{Cl}\end{array}$} & \multirow{2}{*}{\multicolumn{2}{|c|}{$\begin{array}{c}\text { Risk Ratio } \\
\text { M-H, Random, } 95 \% \mathrm{Cl}\end{array}$}} & \\
\hline & Events & Total & Events & Total & & & & & \\
\hline GLASSY & 271 & 3794 & 319 & 3791 & $59.7 \%$ & $0.85[0.73,0.99]$ & & & \\
\hline SMART-CHOICE & 42 & 1495 & 36 & 1498 & $7.5 \%$ & $1.17[0.75,1.81]$ & & & \\
\hline STOPDAPT-2 & 29 & 1500 & 37 & 1509 & $6.2 \%$ & $0.79[0.49,1.28]$ & & & \\
\hline TWILIGHT & 135 & 3555 & 137 & 3564 & $26.6 \%$ & $0.99[0.78,1.25]$ & & & \\
\hline Total $(95 \%$ Cl) & & 10344 & & 10362 & $100.0 \%$ & $0.90[0.80,1.02]$ & & & \\
\hline Total events & 477 & & 529 & & & & & & \\
\hline $\begin{array}{l}\text { Heterogeneity: } \text { Tau }^{2}= \\
\text { Test for overall effect: }\end{array}$ & $\begin{array}{l}0.00 ; \mathrm{Chi}^{2}= \\
\mathrm{Z}=1.70(\mathrm{P}=\end{array}$ & $\mathrm{df}=3(\mathrm{~F}$ & $P=0.42) ; I^{2}=0 \%$ & & & & $0.1 \quad 0.2$ & $\begin{array}{ccc}0.5 & 1 & 2 \\
\text { shortDAPT } & \text { Favours st }\end{array}$ & $\begin{array}{ll}5 & 10 \\
\text { DAPT } & \end{array}$ \\
\hline
\end{tabular}




\section{Myocardial infarction}

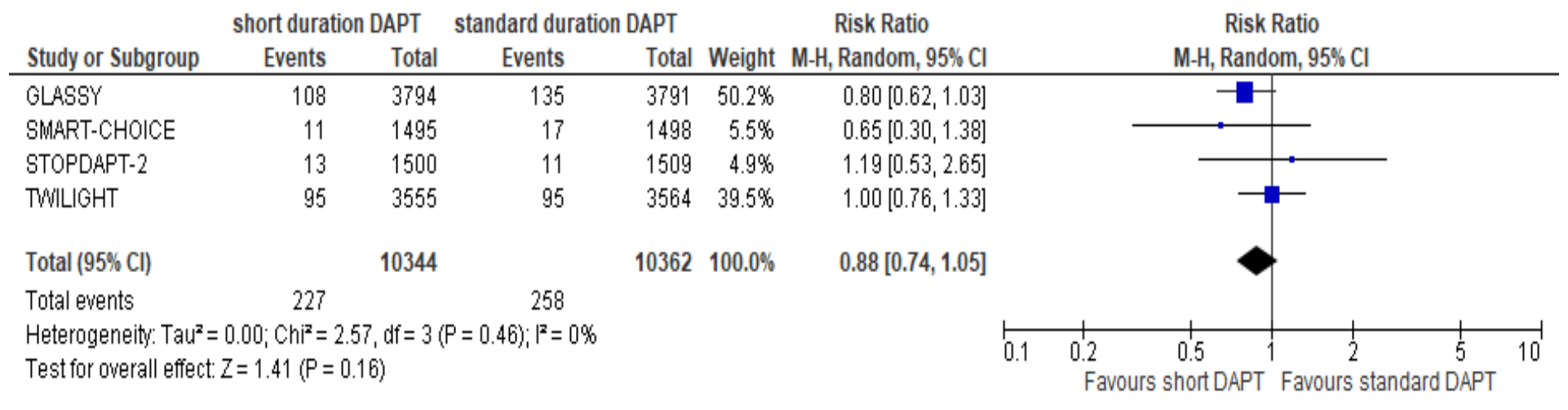

\section{E. Stroke}

short duration DAPT standard duration DAPT

Risk Ratio

Risk Ratio

\begin{tabular}{lrrrrrr} 
Study or Subgroup & Events & Total & Events & Total & Weight & M-H, Random, 95\% Cl \\
\hline GLASSY & 44 & 3794 & 44 & 3791 & $36.3 \%$ & $1.00[0.66,1.51]$ \\
SMART-CHOICE & 11 & 1495 & 5 & 1498 & $18.0 \%$ & $2.20[0.77,6.33]$ \\
STOPDAPT-2 & 8 & 1500 & 16 & 1509 & $22.9 \%$ & $0.50[0.22,1.17]$ \\
TWILIGHT & 16 & 3555 & 8 & 3564 & $22.8 \%$ & $2.01[0.86,4.68]$
\end{tabular}

Total $(95 \% \mathrm{Cl})$

10344

$10362 \quad 100.0 \%$

$1.15[0.65,2.06]$

Total events

$79 \quad 73$

Heterogeneity: Tau $^{2}=0.19 ; \mathrm{Chi}^{2}=7.08, \mathrm{df}=3(\mathrm{P}=0.07) \mathrm{I}^{2}=58 \%$

Test for overall effect: $Z=0.49(P=0.63)$

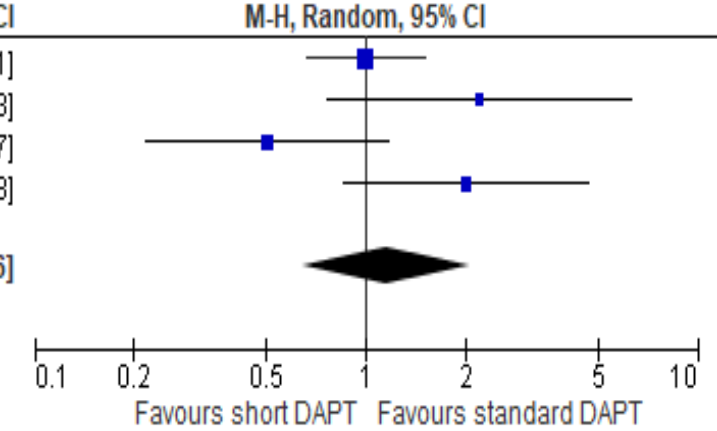

\section{F. Stent thrombosis}

short duration DAPT standard duration DAPT

\begin{tabular}{lrrr} 
Study or Subgroup & Events & Total & Events \\
\hline GLASSY & 33 & 3794 & 46 \\
SMART-CHOICE & 3 & 1495 & \\
STOPDAPT-2 & 4 & 1500 & \\
TWILIGHT & 14 & 3555 & 1
\end{tabular}

Total $(95 \% \mathrm{Cl})$

Total events

10344

54

Heterogeneity: Tau $^{2}=0.00 ; \mathrm{Chi}^{2}=2.84, \mathrm{df}=3(\mathrm{P}=0.42) ; \mathrm{I}^{2}=0 \%$

Test for overall effect: $Z=1.35(P=0.18)$ 68
Risk Ratio

Total Weight M-H, Random, $95 \% \mathrm{Cl}$

$3791 \quad 65.8 \% \quad 0.72[0.46,1.12]$

$1498 \quad 4.1 \% \quad 1.50[0.25,8.98]$

$1509 \quad 2.7 \% \quad 4.02[0.45,35.96]$

$3564 \quad 27.4 \%$

$0.74[0.37,1.47]$

$10362 \quad 100.0 \%$

$0.78[0.54,1.12]$

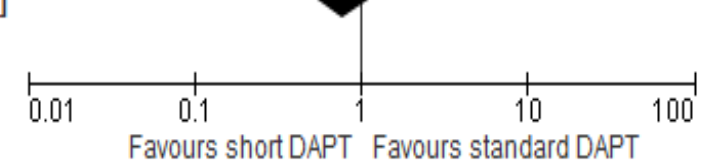




\section{Subgroup analysis}

A subgroup analysis was conducted analysing the bleeding rate and MACE rate in patients presenting with acute coronary syndrome and stable ischaemic heart disease. Sub-group analysis included the GLASSY sub-study, SMART CHOICE and TWILIGHT trials only as they provided data for both bleeding and ischaemic events for these subgroups at 1-year follow up.

In the ACS patients, the bleeding rate showed a highly significant difference between the short DAPT vs standard DAPT; with risk ratio 0.59 (95\% CI 0.47-0.74; $\mathrm{z}=4.56, \mathrm{p}=0.00001$ ) (Figure4 A). The risk of heterogeneity was low $\mathrm{I} 2=10 \%$. For the major adverse cardiovascular events, no significant difference was found between short DAPT and standard DAPT arms (Figure-4 B), risk ratio $0.87(95 \%$ CI $0.75-1.02 ; \mathrm{z}=1.75, \mathrm{p}=0.08)$. The risk of heterogeneity was low $\left(I^{2}=0 \%\right)$.

Figure-4: Forest plot for bleeding events and major adverse cardiovascular events in the subgroup of acute coronary syndrome patients using GLASSY sub-study of GLOBAL

\section{LEADERS trial}

\section{A. Bleeding}

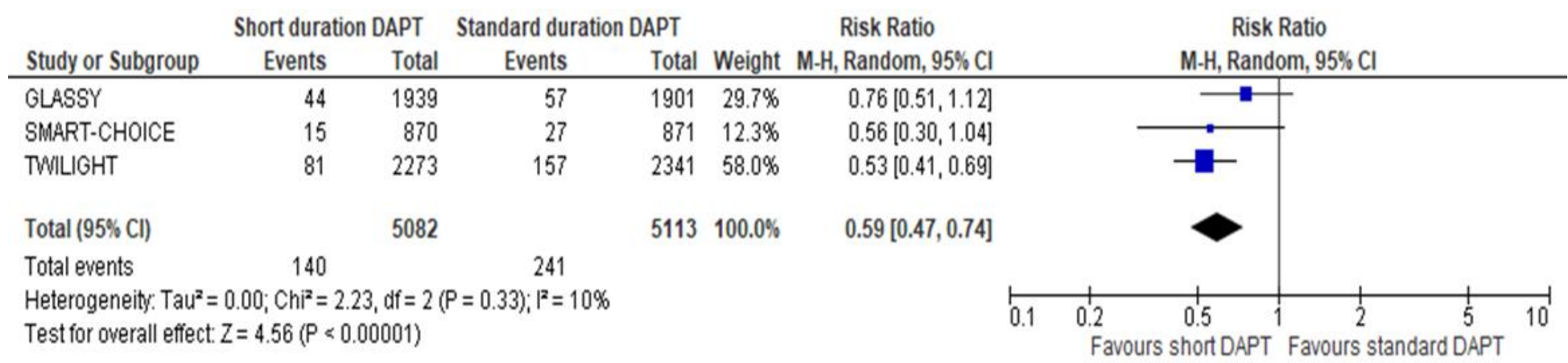

\section{B. Major Adverse Cardiovascular Events (MACE)}




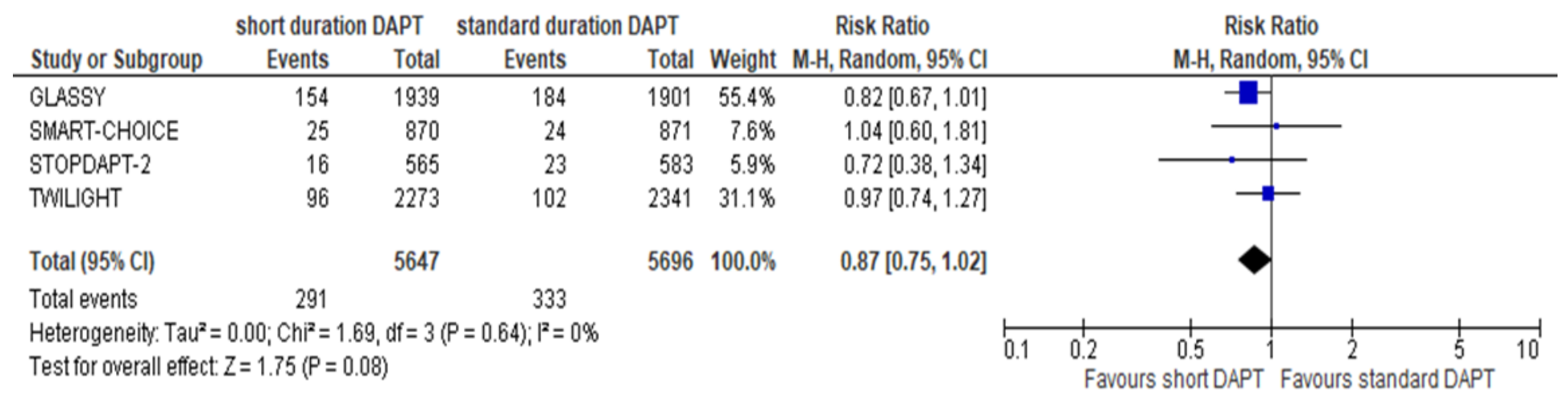

In stable ischaemic heart disease patients, there was no significant difference in the rate of bleeding between short and standard DAPT (Figure-5 A), risk ratio 0.88 (95\% CI 0.55-1.41; $\mathrm{z}=0.51 . \mathrm{p}=0.61$ ), the heterogeneity risk was moderate $\mathrm{I} 2=69 \%$. Also, the rate of major adverse cardiovascular events between both arms showed no significant difference (Figure-5 B), risk ratio $0.91(95 \% \mathrm{CI} 0.70-1.18 ; \mathrm{z}=0.74, \mathrm{p}=0.46)$. The risk of heterogeneity is moderate $\mathrm{I} 2=29 \%$.

Figure-5: Forest plot for bleeding events and major adverse cardiovascular events in the subgroup of stable ischaemic heart disease patients using GLASSY sub-study of GLOBAL LEADERS trial

\section{A. Bleeding}

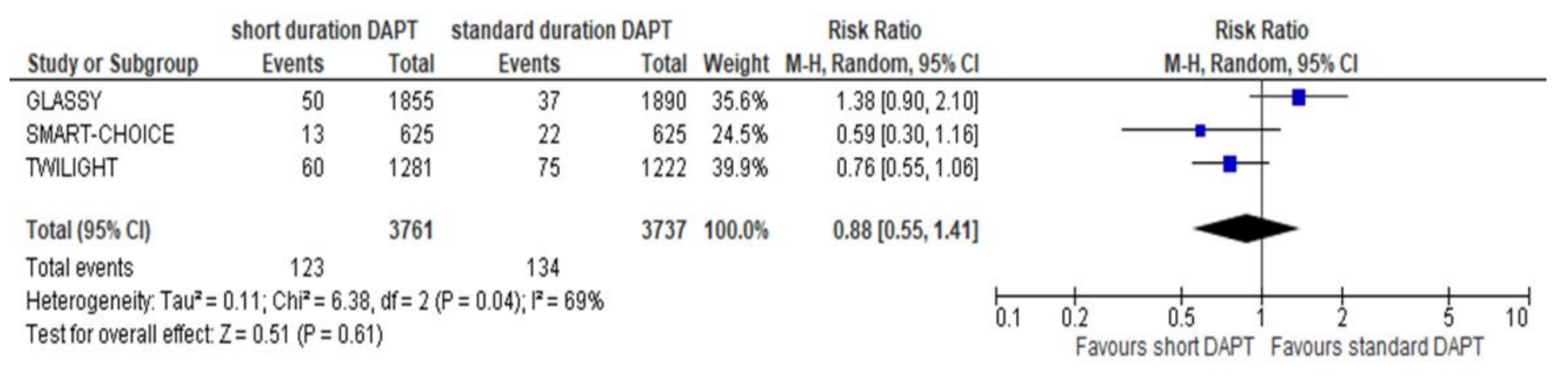




\section{B. Major Adverse Cardiovascular Events (MACE)}

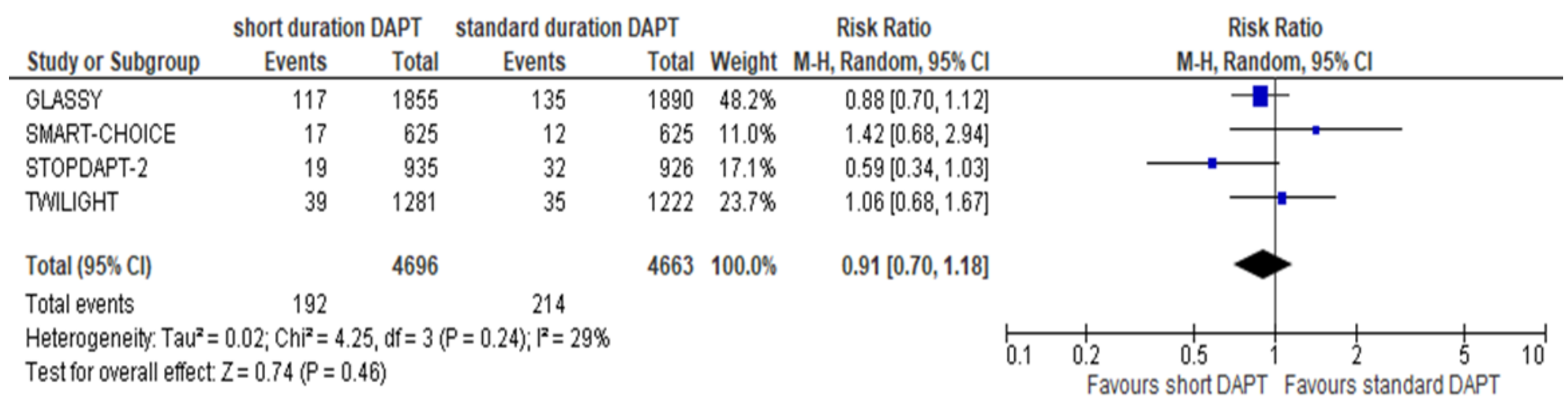

\section{Discussion}

The current meta-analysis assesses short-duration DAPT with early cessation of aspirin versus standard DAPT followed by aspirin alone. There are four major randomised-controlled clinical trials enrolled in the analysis. The findings of this meta-analysis show a favourable risk-benefit ratio of stopping aspirin early after PCI and continue with P2Y12 inhibitor only.

In terms of safety, there is a statistically significant reduction of major bleeding rate with short-duration DAPT followed by P2Y12 inhibitor monotherapy. The results indicate that early discontinuation of aspirin may provide an advantage to patients in term of lowering the mortality and morbidity secondary to bleeding.

Regarding the efficacy, short-duration DAPT followed by P2Y12 inhibitor monotherapy is non-inferior in comparison with standard DAPT regimen. There is no significant difference in ischemic endpoints after PCI including overall mortality, ischaemic MACE, MI, stroke, and stent thrombosis between the two regimens.

The major challenge in patients with coronary artery disease is balancing the risk of ischaemic events (cardiovascular mortality, recurrent ischaemia, and stent thrombosis) against the risk of 
bleeding due to pharmacotherapy. The advances in the technology of newer generation drugeluting stents and the introduction of more potent P2Y12 inhibitors facilitate the testing of new regimens of dual antiplatelet therapy (DAPT). The optimal duration of DAPT is still debatable, especially in patients with a high risk of bleeding.

The concept of lowering the number of antiplatelet agents after PCI is attracting more attention and investigated in an increasing number of studies in the last years. The results of our metaanalysis are consistent with other studies regarding the safety and efficacy of short-duration DAPT ( $\leq 6$ months) $(20-23)$.

Until recently, early discontinuation of aspirin was not considered as an option for patients treated with PCI. New data indicate cessation of aspirin can be possible in PCI patients with a history of atrial fibrillation and anticoagulants use (24).

The risk of bleeding after PCI can be high in a specific group of patients. In patients with acute coronary syndrome and receiving DAPT, the risk of bleeding reaches up to $13 \%$ at 12 months after discharge from the hospital. Interestingly, the bleeding events can be recurrent in $26 \%$ of patients and continue even after cessation of P2Y12 inhibitors (25).

The subgroup analysis of ACS patients in this meat-analysis shows improved outcomes with the short-duration DAPT and P2Y12 inhibitor monotherapy. There is a highly significant reduction in bleeding events without any increase in the ischaemic outcomes in comparison with standard DAPT followed by aspirin.

Our results support the utility of short-duration DAPT followed by P2Y12 inhibitor monotherapy especially with high bleeding risk, intolerance to aspirin; and in cases of emergency or urgent non-cardiac surgery with the need to stop DAPT early.

\section{Limitations}

The limitations of this meta-analysis are related to the differences in the endpoint definitions between the included trials. Secondly, the regimen of P2Y12 inhibitor varied between studies 
with ticagrelor used in both GLOBAL LEADERS and TWILIGHT, clopidogrel in SMARTCHOICE and any P2Y12 inhibitor in STOPDAPT-2. Third, the enrolled patients' population varied in the studies with GLOBAL LEADERS and TWILIGHT trials enrolled multi-ethnic patients; whereas STOPDAPT-2 and SMART-CHOICE were restricted to Asian patients.

Fourth, high-risk patient representation differed across trials with the TWILIGHT trial enrolling only patients with a high risk of ischaemia or bleeding (clinical or angiographic), with the majority of patients in the other three trials being at low to intermediate risk. The highest presentation of the acute coronary syndrome was in TWILIGHT $(64.8 \%$ of the total population), and the lowest was in STOPDAPT-2 (38.1\%).

Another procedural difference across the trials was the high rate of intravascular imaging with more than $80 \%$ of patients in STOPDAPT-2 having IVUS, 25\% in SMART-CHOICE while in GLOBAL LEADERS and TWILIGHT were not specified.

\section{Conclusion}

Short-duration DAPT followed by P2Y12 inhibitor monotherapy after PCI is a feasible option and can be adopted especially in patients with a high risk of bleeding. Further studies are required to confirm the advantages of early aspirin suspension in larger patients' cohorts. 


\section{Abbreviations}

ACS: Acute Coronary Syndrome, SIHD: Stable Ischaemic Heart Disease, MI: myocardial infarction, PCI: Percutaneous coronary intervention, DAPT: Dual Antiplatelet Therapy, MACE: Major Adverse Cardiovascular Events

Funding: no funding resources for this manuscript

Consent for publication: All authors have given their consent on the publication of the manuscript in the journal.

Acknowledgements: None.

Conflict of Interest: The authors report no relationships that could be construed as a conflict of interest. 


\section{References}

1. Mehta SR, Yusuf S, Peters RJ, Bertrand ME, Lewis BS, Natarajan MK, et al. Effects of pretreatment with clopidogrel and aspirin followed by long-term therapy in patients undergoing percutaneous coronary intervention: the PCI-CURE study. Lancet (London, England). 2001;358(9281):527-33.

2. Steinhubl SR, Berger PB, Mann JT, 3rd, Fry ET, DeLago A, Wilmer C, et al. Early and sustained dual oral antiplatelet therapy following percutaneous coronary intervention: a randomized controlled trial. Jama. 2002;288(19):2411-20.

3. Palmerini T, Stone GW. Optimal duration of dual antiplatelet therapy after drugeluting stent implantation: conceptual evolution based on emerging evidence. European heart journal. 2016;37(4):353-64.

4. Mauri L, Kereiakes DJ, Yeh RW, Driscoll-Shempp P, Cutlip DE, Steg PG, et al. Twelve or 30 months of dual antiplatelet therapy after drug-eluting stents. New England journal of medicine. 2014;371(23):2155-66.

5. Costa F, van Klaveren D, James S, Heg D, Raber L, Feres F, et al. Derivation and validation of the predicting bleeding complications in patients undergoing stent implantation and subsequent dual antiplatelet therapy (PRECISE-DAPT) score: a pooled analysis of individual-patient datasets from clinical trials. Lancet (London, England).

2017;389(10073):1025-34.

6. Valgimigli M, Bueno H, Byrne RA, Collet J-P, Costa F, Jeppsson A, et al. 2017 ESC focused update on dual antiplatelet therapy in coronary artery disease developed in collaboration with EACTS: The Task Force for dual antiplatelet therapy in coronary artery disease of the European Society of Cardiology (ESC) and of the European Association for Cardio-Thoracic Surgery (EACTS). European heart journal. 2017;39(3):213-60.

7. A randomised, blinded, trial of clopidogrel versus aspirin in patients at risk of ischaemic events (CAPRIE). CAPRIE Steering Committee. Lancet. 1996;348(9038):132939.

8. Yuan J, Xu GM, Ding J. Aspirin Versus Clopidogrel Monotherapy for the Treatment of Patients with Stable Coronary Artery Disease: A Systematic Review and Meta-Analysis. Advances in therapy. 2019;36(8):2062-71.

9. Cannon CP, Bhatt DL, Oldgren J, Lip GYH, Ellis SG, Kimura T, et al. Dual Antithrombotic Therapy with Dabigatran after PCI in Atrial Fibrillation. The New England journal of medicine. 2017;377(16):1513-24.

10. Dewilde WJ, Oirbans T, Verheugt FW, Kelder JC, De Smet BJ, Herrman JP, et al. Use of clopidogrel with or without aspirin in patients taking oral anticoagulant therapy and undergoing percutaneous coronary intervention: an open-label, randomised, controlled trial. Lancet. 2013;381(9872):1107-15.

11. Gibson CM, Mehran R, Bode C, Halperin J, Verheugt FW, Wildgoose P, et al. Prevention of Bleeding in Patients with Atrial Fibrillation Undergoing PCI. The New England journal of medicine. 2016;375(25):2423-34. 
12. Lopes RD, Heizer G, Aronson R, Vora AN, Massaro T, Mehran R, et al. Antithrombotic Therapy after Acute Coronary Syndrome or PCI in Atrial Fibrillation. The New England journal of medicine. 2019;380(16):1509-24.

13. Moher D, Liberati A, Tetzlaff J, Altman DG. Preferred reporting items for systematic reviews and meta-analyses: the PRISMA statement. Annals of internal medicine. 2009;151(4):264-9, w64.

14. Mehran R, Rao SV, Bhatt DL, Gibson CM, Caixeta A, Eikelboom J, et al. Standardized bleeding definitions for cardiovascular clinical trials: a consensus report from the Bleeding Academic Research Consortium. Circulation. 2011;123(23):2736-47. 15. Vranckx P, Valgimigli M, Juni P, Hamm C, Steg PG, Heg D, et al. Ticagrelor plus aspirin for 1 month, followed by ticagrelor monotherapy for 23 months vs aspirin plus clopidogrel or ticagrelor for 12 months, followed by aspirin monotherapy for 12 months after implantation of a drug-eluting stent: a multicentre, open-label, randomised superiority trial. Lancet. 2018;392(10151):940-9.

16. Hahn JY, Song YB, Oh JH, Chun WJ, Park YH, Jang WJ, et al. Effect of P2Y12 Inhibitor Monotherapy vs Dual Antiplatelet Therapy on Cardiovascular Events in Patients Undergoing Percutaneous Coronary Intervention: the SMART-CHOICE Randomized Clinical Trial. JAMA. 2019;321(24):2428-37.

17. Watanabe H, Domei T, Morimoto T, Natsuaki M, Shiomi H, Toyota T, et al. Effect of 1-Month Dual Antiplatelet Therapy Followed by Clopidogrel vs 12-Month Dual Antiplatelet Therapy on Cardiovascular and Bleeding Events in Patients Receiving PCI: The STOPDAPT-2 Randomized Clinical Trial. Jama. 2019;321(24):2414-27.

18. Mehran R, Baber U, Sharma SK, Cohen DJ, Angiolillo DJ, Briguori C, et al. Ticagrelor with or without Aspirin in High-Risk Patients after PCI. The New England journal of medicine. 2019;381(21):2032-42.

19. Franzone A, McFadden E, Leonardi S, Piccolo R, Vranckx P, Serruys PW, et al. Ticagrelor Alone Versus Dual Antiplatelet Therapy From 1 Month After Drug-Eluting Coronary Stenting. Journal of the American College of Cardiology. 2019;74(18):2223-34. 20. Yin S-H-L, Xu P, Wang B, Lu Y, Wu Q-Y, Zhou M-L, et al. Duration of dual antiplatelet therapy after percutaneous coronary intervention with drug-eluting stent: systematic review and network meta-analysis. BMJ (Clinical research ed). 2019;365:12222. 21. Misumida N, Abo-Aly M, Kim SM, Ogunbayo GO, Abdel-Latif A, Ziada KM. Efficacy and safety of short-term dual antiplatelet therapy ( $\leq 6$ months) after percutaneous coronary intervention for acute coronary syndrome: A systematic review and meta-analysis of randomized controlled trials. Clinical cardiology. 2018;41(11):1455-62.

22. Lee SY, Hong MK, Palmerini T, Kim HS, Valgimigli M, Feres F, et al. Short-Term Versus Long-Term Dual Antiplatelet Therapy After Drug-Eluting Stent Implantation in Elderly Patients: A Meta-Analysis of Individual Participant Data From 6 Randomized Trials. JACC Cardiovascular interventions. 2018;11(5):435-43.

23. Verdoia M, Kedhi E, Suryapranata H, Frati G, Biondi-Zoccai G, De Luca G. Benefits of short-term or prolonged as compared to standard 1 year DAPT in patients with acute coronary syndrome treated with drug-eluting stents: a meta-analysis of 9 randomized trials. Journal of thrombosis and thrombolysis. 2020.

24. Haller PM, Sulzgruber P, Kaufmann C, Geelhoed B, Tamargo J, Wassmann S, et al. Bleeding and ischaemic outcomes in patients treated with dual or triple antithrombotic therapy: systematic review and meta-analysis. European heart journal Cardiovascular pharmacotherapy. 2019;5(4):226-36.

25. Ismail N, Jordan KP, Kadam UT, Edwards JJ, Kinnaird T, Mamas MA. Bleeding After Hospital Discharge Following Acute Coronary Syndrome: Incidence, Types, Timing, and Predictors. Journal of the American Heart Association. 2019;8(21):e013679. 
